\title{
Learning History of Hindu-Buddha Removal to Invest in The Value of Local Authenticity in The Middle School Students
}

\author{
Meli Febriani \\ Universitas Sebelas Maret \\ melyfebriani123@gmail.com
}

\author{
Article History \\ accepted 1/09/2020
}

approved 4/10/2020

published 1/12/2020

\begin{abstract}
Cultural relics in the Hindu-Buddhist era in the form of temples are part of local history that can provide positive values for students. The temple, which contains artifacts in the form of souvenirs, provides interesting local history material when it is explained with great inspiration by an innovative and creative teacher. This research was studied using a qualitative approach. The data collection process was carried out by means of observation, interviews, and document study. This research is aimed at seeing the importance of the legacy of a civilization, namely the temple, to be put forward in local history learning materials. This is a means for the formation of national identity through historical awareness and cultural awareness, as well as a teacher or teacher approach to introducing students to local wisdoms that exist around them. Learning like this will make students understand the history of themselves or their environment.
\end{abstract}

Keywords: History learning, local genius, local history

\begin{abstract}
Abstrak
Peninggalan kebudayaan di masa Hindu-Buddha berupa Candi merupakan bagian dari sejarah local yang mampu memberikan nilai positif bagi siswa. Candi yang terdapat didalamnya buah tangan berbentuk artefak memberikan materi sejarah local yang menarik apabila dijelaskan dengan penuh penjiwaan oleh guru yang inovatif dan kreatif. Penelitian ini dikaji dengan menggunakan pendekatan kualitatif. Proses pengumpulan data dilakukan dengan cara observasi, wawancara, dan studi dokumen. Penelitian ini ditujukan untuk melihat pentingnya peninggalan sebuah peradaban yakni candi untuk dikedepankan dalam materi pembelajaran Sejarah local. Hal ini merupakan sarana untuk pembentukan jati diri bangsa melalui kesadaran sejarah dan kesadaran budaya, juga sebagai pendekatan seorang guru atau pengajar untuk mengenalkan kepada anak didik tentang kearifan-kearifan lokal yang ada di sekitar mereka. Pembelajaran seperti ini akan menjadikan anak didik paham dengan sejarah diri atau lingkungannya.
\end{abstract}

Kata kunci : Pembelajaran sejarah, kearifan lokal, sejarah lokal

Social, Humanities, and Education Studies (SHEs): Conference Series

p-ISSN 2620-9284 https://jurnal.uns.ac.id/shes

e-ISSN 2620-9292 


\section{PENDAHULUAN}

Peninggalan kebudayaan dapat menjadikan upaya pendekatan kepada siswa pada pembelajaran sejarah, yaitu dengan memasukkan unsur-unsur peninggalan kebudayaan yang berbasis kepada kearifan local. Unsur-unsur kearifan local terdapat pada sejarah local, yang mana dapat dihubungkan pada tema sejarah nasional. Muatan kearifan lokal sebagai bagian dari sejarah lokal dapat digunakan oleh guru untuk membantu mengembangkan keterampilan berpikir sejarah seperti analisis sumber, pengumpulan data, dan penciptaan argumen sejarah (Marino, 2012). Input dari nilainilai kearifan local ini diharapkan mampu untuk mendorong peserta didik untuk memahami kearifan local di daerahnya sendiri, sehingga nantinya akan menumbuhkan rasa cinta peserta didik terhadap budayanya dan pada akhirnya peserta didik tersebut memiliki identitas diri dalam memperkokok rasa kecintaan terhadap negerinya.

Kearifan lokal merupakan bagian dari budaya suatu masyarakat yang tidak dapat dipisahkan dari bahasa masyarakat itu sendiri. Kearifan lokal (local wisdom) biasanya diwariskan secara turun temurun dari satu generasi ke generasi melalui cerita dari mulut ke mulut. Kearifan lokal ada di dalam cerita rakyat, peribahasa, lagu, dan permainan rakyat. Kearifan lokal sebagai suatu pengetahuan yang ditemukan oleh masyarakat lokal tertentu melalui kumpulan pengalaman dalam mencoba dan diintegrasikan dengan pemahaman terhadap budaya dan keadaan alam suatu tempat. Di tengah pusaran pengaruh hegemoni global, fenomena yang terjadi telah membuat lembaga pendidikan serasa kehilangan ruang gerak. Selain itu juga membuat semakin menipisnya pemahaman peserta didik tentang sejarah lokal serta tradisi budaya yang ada dalam masyarakat. Oleh karena itu, alangkah lebih baiknya jika diupayakan bagaimana caranya agar aneka ragam budaya yang telah dimiliki dapat dijaga dan dilestarikan bersama. Dengan pendidikan yang berbasis pada local wisdom (kearifan lokal) maka akan terciptanya pendidikan yang mampu memberi makna bagi kehidupan manusia Indonesia. Artinya pendidikan kemudian akan mampu menjadi spirit yang bisa mewarnai dinamika manusia Indonesia ke depan.

Pendidikan berbasis kearifan lokal adalah pendidikan yang mengajarkan siswa untuk selalu lekat dengan situasi konkret yang mereka hadapi, dengan dihadapkan pada masalah dan situasi konkret yang dihadapi, siswa akan semakin tertantang untuk menanggapinya secara kritis dan melatih keaktifan dan kemandirian siswa. Pendidikan sejarah terdapat nilai-nilai yang dapat diwariskan dan ditanamkan, salah satunya adalah nilai religius dan nasionalisme. Seperti pada materi proses masuknya agama Hindhu dan Buddha (Winarsih, 2017). Pembelajaran Sejarah materi perkembangan dan pengaruh agama Hindhu-Buddha di Indonesia penting untuk disampaikan kepada siswa, budaya yang saat ini ada bukan muncul secara tiba-tiba, namun melalui proses yang panjang. Banyak kebudayaan dari luar Nusantara yang turut berpengaruh terhadap berkembangnya peradaban dan kebudayaan Indonesia. Salah satunya adalah kedatangan pengaruh Hindhu-Buddha di Nusantara. Pada akhirnya mempengaruhi beberapa aspek kehidupan masyarakat yang berkembang, salah satunya adalah sistem pemerintahan. Pengaruh inilah yang mengawali munculnya kerajaan-kerajaan tersebar di Nusantara.

Berdasarkan beberapa permasalahan yang ada dibeberapa sekolah di Kota Jambi, kurangnya pemahaman guru dan siswa terhadap situs-situs peninggalan sejarah sangat mempengaruhi pada kualitas pembelajaran sejarah, sehingga menyebabkan siswa sulit memahami materi sejarah local (local wisdom). Selain itu, bentuk-bentuk implementasi kearifan lokal pada pembelajaran guru hanya memberikan gambaran-gambaran umum tentang sejarah masa hindu-buddha, pada hal dalam melakukan pemanfaatan dengan mengunjungi langsung benda-benda peninggalan sejarah masa Hindhu-Buddha yang ada di Candi Muaro Jambi efektivitas belajar kepada peserta didik lebih menjamin. Beberapa siswa pasti sudah pernah melakukan 
perjalanan ke Candi Muaro Jambi namun hal tersebut dilakukan sekadar wisata di luar KBM.

Peninggalan kebudayaan Hindhu-Buddha di Jambi yang berkembang saat itu di Nusantara meninggalkan warisan budaya yang luar biasa, dimana peninggalanpeninggalan kerajaan Hindhu-Buddha tersebut dapat dikenalkan kepada siswa dengan harapan siswa dapat menjaga warisan peradaban Indonesia masa lampau untuk generasi yang akan datang.

\section{METODE PENELITIAN}

Penelitian ini menggunakan metode kualitatif deskriptif. Menurut Sugiono, penelitian kualitatif adalah penelitian dimana peneliti ditempatkan pada instrument kunci, teknik pengumpulan data dilakukan secara penggabungan dan analisis data bersifat induktif (Sugiono, 2010 : 9). Menurut Poerwandari (2005), penelitian kualitatif menghasilkan dan mengolah data yang sifatnya deskriptif, seperti transkripsi wawancara dan observasi. Kirk dan Miller ( dalam moloeng) mendefinisikan penelitian kualitatif sebagai cara melakukan pengamatan langsung pada individu dan berhubungan pada orang-orang untuk mendapatkan data-data yang digalinya (moleong, J.L $2002: 3$ ).

Dasar pemikiran digunakannya metode ini adalah ingin mengetahui fenomena yang ada dan dalam kondisi yang alamiah, bukan dalam kondisi terkendali, laboratoris atau eksperimen. Selain itu penggunaan metode ini dikarenakan ada beberapa petimbangan diantaranya adalah penelitian ini bersifat menggambarkan, menguraikan suatu hal, maksudnya adalah data yang dikumpulkan adalah berupa kata-kata atau penalaran, hal ini disebabkan oleh adanya penerapan kualitatif, penyajian data dilakukan secara langsung yakni hubungan peneliti dengan responden.

\section{HASIL DAN PEMBAHASAN}

Pembelajaran sejarah yang bermaterikan pada kerajaan Hindu-Buddha di Nusantara mengacu pada Kurikulum 2013 yang terdapat pada Kompetensi Dasar 3.5 dan 3.6 kelas X mata pelajaran Sejarah Indonesia. Dalam kurikulum 2013, pendekatan saintifik (mengamati, menanya, mengumpulkan informasi, mengasosiasi, dan mengomunikasikan) akan menjadi roh pembelajaran dengan berbagai model pembelajaran. Tiga model yang dikembangkan dalam Kurikulum 2013, seperti PBL (Problem Based Learning), DL (Discovery Learning), dan PjBL (Project Based Learning), akan dapat mengembangkan pembelajaran sejarah lokal secara optimal. Kurikulum 2013 pada pendidikan sejarah lebih mempertegas tujuan dari pembelajaran sejarah di sekolah yang mendorong siswa agar berfikir kreatif dan kritis. Hasan (2012) mengemukakan bahwa "Dalam wilayah pendidikan, sejarah harus menjadi sesuatu yang memberikan pelajaran bagi kehidupan manusia. Peristiwa-peristiwa sejarah dilihat dengan pendekatan normatif, dengan melihat baik dan buruk." Jadi kurikulum 2013 akan membentuk siswa yang memiliki kualitas yang baik, sehingga mampu mengambil nilai baik dan buruknya dari peristiwa sejarah di masa lampau.

Pada Kurikulum 2013 pendidikan sejarah lebih mempertegas tujuan dari pembelajaran sejarah di sekolah yang mendorong peserta didik agar berfikir kreatif dan kritis. Hasan (2012: iv) mengemukakan bahwa "Dalam wilayah pendidikan, sejarah harus menjadi sesuatu yang memberikan pelajaran bagi kehidupan manusia. Peristiwa-peristiwa sejarah melihat ini dengan pendekatan normatif, dan melihat baik dan buruknya.

Kearifan sejarah lokal (local wisdom) merupakan nilai-nilai atau kebijakan yang dimiliki masyarakat lokal atau daerah yang diwariskan secara turun-temurun dari satu generasi ke generasi berikutnya. Nilai-nilai lokal antara lain berupa filosofi dan pandangan hidup yang mewujud dalam berbagai bidang kehidupan seperti tata nilai 
sosial dan ekonomi, arsitektur, kesehatan, tata lingkungan dan sebagainya (Romadi dan Kurniawan, 2017: 84). Bagi masyarakat pendukungnya, kearifan lokal diyakini sebagai kepemilikan budaya, dan wajib dilestarikan sebagai wujud rasa hormat pada budaya para leluhurnya.

Keterkaitan antara materi pembelajaran tentang Hindu-Buddha dan penanaman nilai kearifan sejarah local saling beririsan, karena peninggalan-peninggalan hindubuddha berbentuk benda seperti artefak memberikan suatu budaya local yang menarik dan harus dilestarikan agar kepribadian bangsa tidak tergerus oleh budaya-budaya asing yang masuk. Seperti pada kurikulum 2013 pendidikan sejarah lebih menekankan pada tujuan dari pembelajaran sejarah sehingga mendorong peserta didik agar berfikir kreatif dan kritis. Bagaimana cara agar siswa dapat mengimplemantasikannya? Salah satu caranya adalah dengan memasukkan materi tentang hindu-buddha beserta peninggalannya di dalam sub kompetensi dasar pada silabus. Guru disini harus bersikap kreatif dalam memberikan materi tersebut. Agar tujuan pembelajaran dapat tercapai dan konsep tentang penanaman nilai kearifan local kepada siswa dapat tersampaikan dan dapat di aplikasikan ke kehidupan sehari-hari.

Moh. As'ad dalam jurnal psikologi UGM 2011 Studi Eksplorasi Konstrak Kepemimpinan Model Jawa Asta Brata mengungkapkan bahwa salah satu isu sentral dalam dunia psikologi adalah banyaknya penelitian-penelitian tipikal psikologi yang cenderung mengarah pada fondasi, ide dan instrumentasi dari dunia barat. Sedangkan penelitian di barat memiliki batasan budaya (culture bound). Hasil penelitian Moh. As'ad sejalan dengan penelitian ini yaitu pembelajaran sejarah peninggalan Hindu Buddha untuk menanamkan nilai kearifan local bahwa pada esensinya konstrak Peninggalan Hindu-buddha yang masih ada hingga saat ini merupakan model pengukuran multidimensi yang secara teoritik digunakan untuk mengukur karakter siswa.

Pendidikan berbasis kearifan lokal adalah pendidikan yang mengajarkan siswa untuk selalu lekat dengan situasi konkret yang mereka hadapi. Dengan dihadapkan pada masalah dan situasi konkret yang dihadapi, siswa akan semakin tertantang untuk menanggapinya secara kritis dan melatih keaktifan dan kemandirian siswa. Pendidikan juga harus memperhatikan sinergitas antar budaya dengan pendidikan agar pendidikan yang berlangsung lebih memiliki karakter dan lebih sesuai dengan budaya yang berkembang sehingga akan lebih mudah diterima dan diaplikasikan oleh siswa dalam kehidupannya. Hal ini dapat dijadikan sebagai sumber materi dan nilai-nilai yang harus ditanamkan dalam pembelajaran sejarah di sekolah. Pembelajaran sejarah dengan basis kearifan lokal akan menggugah minat siswa, terutama dalam menyadari dan memahami mulutikuluralisme, sehingga siswa akan lebih luwes dan sukses dalam pergaulan kehidupan yang sesungguhnya. Menurut Saraswati (2011) "sejarah suatu bangsa memunculkan nilai-nilai luhur oleh masing-masing bangsa. Karena itu, kebijakan dan karekter bangsa diperoleh dari sejarah.

Kearifan lokal sesungguhnya mengandung banyak sekali keteladanan dan kebijaksanaan hidup. Pentingnya kearifan lokal dalam pendidikan secara luas adalah bagian dari upaya meningkatkan ketahanan nasional sebagai identitas sebuah bangsa. Berdasarkan pengamatan yang dilakuka penanaman nilai-nilai kearifan lokal pada mata pelajaran sejarah pokok bahasan perkembangan Hindu-Buddha di Indonesia akan lebih mudah diserap oleh siswa apabila disertai dengan contoh nyata yang diberikan oleh guru terkait kearifan-kearifan yang ada di lingkungan sekitar.

Penanaman kearifan lokal yang dilakukan oleh guru di dalam kelas bisa dengan cara yakni dengan cara menulis dan menerangkan namun secara detail dan menyeluruh, kemudian memberikan tugas kepada siswa untuk membuat peta konsep mengenai teori-teori masukknya agama Hindhu-Buddha, menampilkan slide berupa gambar dan video yang berkaitan dengan materi perkembangan agama HindhuBuddha di Indonesia yang di dalamnya terdapat contoh budaya daerah seperti video tentang sejarah kompleks percandian Muaro Jambi dimana candi tersebut berada di 
dekat wilayah Muara Jambi, melakukan diskusi kelompok tentang kerajaan- kerajaan Hindhu-Buddha yang ada di Indonesia beserta hasil kebudayaannya yang harus dijaga.

Metode dan model pembelajaran juga sangat mempengaruhi dalam keberhasilan guru dalam menanamkan nilai kearifan local kepada siswa. dengan metode ceramah bervariasi, dongeng atau bercerita (telling story). Metode ini memudahkan guru untuk mengkaitkan materi dengan kondisi nyata yang dialami siswa. Guru biasanya mengimplementasikan nilai-nilai kearifan lokal pada tengah-tengah materi yang disampaikan dan pada saat refleksi materi. Metode mengajar akan lebih bervariasi, tidak semata-mata komunikasi verbal melalui penuturan kata-kata oleh guru sehingga siswa tidak bosan dan guru tidak kehabisan tenaga. Siswa akan lebih banyak melakukan kegiatan belajar, sebab tidak hanya mendengarkan uraian guru, tetapi juga aktivitas lain seperti mengamati, melakukan, mendemostrasikan dll.

\section{Kesimpulan}

Kearifan lokal merupakan nilai-nilai lokal antara lain meliputi keyakinan, normanorma, sikap, karakter, pengetahuan, filosofi yang diwariskan dari generasi ke generasi berikutnya. Kearifan lokal ini bagi masyarakat pendukungnya diyakini sebagai suatu kebenaran dan dilestarikan sebagai wujud kepemilikan budaya dan bentuk penghormatan kepada budaya para leluhurnya.

Kearifan lokal bersumber pada kebudayaan lokal, baik berkaitan dengan sistem nilai, tradisi lisan, budaya abstrak, perilaku atau tindakan, foklor sebagian lisan, gotong royong, upacara keagamaan, kesenian rakyat dan lain-lain serta artefact (kebudayaan benda seperti, relief, ukirukiran). Dalam rangka untuk melestarikan kearifan lokal sebaiknya guru sejarah mengidentifikasi/menggali kearifan lokal yang ada di daerahnya untuk dikenalkan, disosialisasikan pada peserta didik melalui pengintegrasian atau penanaman kearifan lokal dalam pembelajaran sejarah. Pengintegrasian atau penanaman kearifan lokal dalam pembelajaran sejarah secara garisnya dilakukan melalui dua cara yaitu; (1) melalui keteladanan, pembiasaan, dan budaya sekolah, (2) pembelajaran efektif sehingga diperoleh nilai-nilai lokal sebagai efek/dampak pengiring.

\section{Daftar Pustaka}

Ankersmit, F.R.. 1987. Refleksi Tentang Sejarah, Pendapat-pendapat Modern Tentang Filsafat Sejarah. Jakarta: PT Gramedia.

Hasan, S. H. 2014. Pendidikan Sejarah Dalam Kurikulum 2013. Solo: Direktorat Sejarah, Direktorat Jenderal Kebudayaan, Kementerian Pendidikan dan Kebudayaan.

Marino, Michael P. (2012). "Urban Space as a Primary Source: Local History and Historical Thinking in New York City". Dalam Social Studies. Vol. 103. No. 3. Hal. 107.

Moleong, Lexy J. 2000. Metodologi Penelitian Kualitatif. Bandung: PT Remaja Rosdakarya.

Saraswati, U. (2011). "The Significance and Purpose of Ancient Manuscript for the Nation's Culture and Character Development Through the History 
Teaching". Dalam International Jurnal of History Education. Vol. 12 No. 1. Hal1.

Sugiyono. 2009. Metodologi Penelitian Kualitaif, Kuantitatif, dan R\&D.

Bandung: Alfabeta.

Winarsih, I. (2017). "Peranan Pembelajaran Sejarah dalam Penanaman Nilai Karakter Religius dan Naionalisme di MAN Temanggung Tahun Ajaran 2016/2017". Skripsi. Semarang: Fakultas IImu Sosial Universitas Negeri Semarang. 